\title{
Comparison of the effects of microwave and spark plasma sintering on the electrical, thermal, and mechanical properties of $\mathrm{Cu}-\mathrm{LaB}_{6}$ nanocomposites
}

\author{
Mikrodalga ve kivilcum plazma sinterlemenin Cu-LaB, nanokompozitlerin elektriksel, ısil ve \\ mekanik özellikleri üzerindeki etkilerinin karşılaştırılması
}

\author{
Ege Anıl DÍLER ${ }^{* 1, a}$ \\ ${ }^{1}$ Ege University, Faculty of Engineering, Department of Mechanical Engineering, 35040, Izmir, Turkey
}

\begin{tabular}{|c|c|c|}
\hline • Geliş tarihi / Received: 23.04 .2021 & • Düzeltilerek geliş tarihi / Received in revised form: 08.09.2021 & - Kabul tarihi / Accepted: 18.09.2021 \\
\hline
\end{tabular}

\begin{abstract}
The effects of lanthanum hexaboride $\left(\mathrm{LaB}_{6}\right)$ nano-particles on the electrical, thermal, and mechanical properties of copper-based nanocomposites $\left(\mathrm{Cu}-\mathrm{LaB}_{6}\right)$ produced using microwave sintering (MS) and spark plasma sintering (SPS) processes were investigated in this study. Nano $\mathrm{LaB}_{6}$ particles reduced the electrical conductivity of $\mathrm{Cu}$ matrix nanocomposites produced via MS and SPS by $20 \%$ and $13 \%$, respectively. $\mathrm{Cu}-\mathrm{LaB}_{6}$ nanocomposites had lower thermal conductivity than unreinforced $\mathrm{Cu}$. The electrical and thermal conductivities of the $\mathrm{Cu}-\mathrm{LaB}_{6}$ nanocomposite produced by the SPS process were higher than those of the $\mathrm{Cu}-\mathrm{LaB}_{6}$ nanocomposite produced by the MS process. An equation that takes particle volume ratio and porosity into account was developed to predict the thermal conductivity of nanocomposites from their electrical conductivity. The calculated thermal conductivity values for $\mathrm{Cu}-\mathrm{LaB}_{6}$ nanocomposites were very close to the experimental results. $\mathrm{Cu}-\mathrm{LaB}_{6}$ nanocomposites had much higher hardness and compressive strength by $49 \%$ and $38 \%$, respectively, compared to those of unreinforced $\mathrm{Cu}$. The hardness and compressive strength of the $\mathrm{Cu}-\mathrm{LaB}_{6}$ nanocomposite produced by SPS were higher than those of the $\mathrm{Cu}-\mathrm{LaB}_{6}$ nanocomposite manufactured via MS. Although nano $\mathrm{LaB}_{6}$ reinforcement particles reduced the electrical and thermal conductivities of $\mathrm{Cu}, \mathrm{Cu}-\mathrm{LaB}_{6}$ nanocomposite having high hardness and compressive strength were produced by combining the positive influences of nano $\mathrm{LaB}_{6}$ reinforcement particles and the SPS process.
\end{abstract}

Keywords: Copper, Electrical and thermal conductivity, Microwave sintering, Nanocomposite, Nano-LaB 6 , Spark plasma sintering

\section{$\ddot{O} z$}

Çalışmada, nano lantan heksaborid (LaB 6 ) partiküllerinin, mikrodalga sinterleme (MS) ve klvllcum plazma sinterleme (SPS) işlemleri kullanılarak üretilen bakır esasl nanokompozitlerin (Cu-LaB, elektriksel, ısıl ve mekanik özellikleri üzerine etkileri araşstırlmış̧tı. Nano LaB 6 partikülleri, MS ve SPS ile üretilen Cu matrisli nanokompozitlerin elektrik iletkenliğini sırastyla \% 20 ve \% 13 oranında azalmasina neden olmuştur. Cu-LaB ${ }_{6}$ nanokompozitleri, takviyesiz Cu'dan daha düşük termal iletkenliğe sahip olmuştur. SPS metodu ile üretilen Cu-LaB, nanokompozitinin elektriksel ve isll iletkenlikleri, MS ile üretilen Cu-LaB ${ }_{6}$ nanokompozitinden daha yüksek olmuştur. Nanokompozitlerin isll iletkenliğini elektriksel iletkenliklerinden hesaplayabilmek için partikül hacim oranını ve gözenekliliği dikkate alan bir denklem geliş̧tirilmiştir. Cu-LaB 6 nanokompozitler için hesaplanan ssıl iletkenlik değerleri deneysel sonuçlara oldukça yakın sonuçlar vermiştir. $\mathrm{Cu}$-LaB ${ }_{6}$ nanokompozitleri, takviye edilmemiş Cu malzemelere göre siraslyla \% 49 ve \% 38 oraninda daha yüksek sertliğe ve basma dayanımina sahip olmuştur. SPS yöntemi ile üretilen Cu-LaB 6 nanokompozitinin sertliği ve basma dayanımı, MS ile üretilen Cu-LaB 6 nanokompozitinden daha yüksek olmuştur. Nano LaB 6 partiküllerinin, Cu'nun elektriksel ve isl iletkenliklerinin bir miktar düşmesine neden olmasına rağmen, nano LaB 6 partikülleri ile SPS işleminin olumlu etkileri biraraya getirilerek, yüksek sertlik ve basma dayanımına sahip Cu-LaB 6 nanokompozit üretilmiştir.

Anahtar kelimeler: Bakır, Elektriksel ve isl iletkenlik, Mikrodalga sinterleme, Nanokompozit, Nano-LaB, Kıvllcum plazma sinterleme

\footnotetext{
${ }^{{ }^{*} a}$ Ege Anıl DILLER; ege.anil.diler@ege.edu.tr; Tel: (0232) 31151 28; orcid.org/0000-0002-1667-5737
} 


\section{Introduction}

Copper is one of the most common metallic materials used in a variety of applications such as electronics and machinery due to its high electrical and thermal conductivities and remarkable mechanical properties (Schipper et al., 2018; Li et al., 2020). Although copper has such good properties, its high thermal expansion and low wear resistance restrict its use in some applications. Copper $(\mathrm{Cu})$ matrix composites are potential materials for overcoming these drawbacks of copper and allowing it to be used in applications such as brushes of DC motor and fusion heat sinks (Raj et al., 2018; Tejado et al., 2018).

$\mathrm{Cu}$ matrix composites have been developed by reinforcing $\mathrm{Cu}$ with various reinforcement particles such as $\mathrm{TiB}_{2}$ (Ren et al., 2019), TiC (Afzal and Harish, 2020), WC (Dias et al., 2019), $\mathrm{ZrO}_{2}$ (Fathy et al., 2019), $\mathrm{SiC}$ (Somani et al., 2018), $\mathrm{Al}_{2} \mathrm{O}_{3}$ (Strojny-Nędza et al., 2018), and NbC (Bian et al., 2021). The electrical, thermal, and mechanical properties of $\mathrm{Cu}$ matrix composites vary depending on factors such as reinforcement particles and production processes. For example, the hardness, tensile strength, and wear resistance of $\mathrm{Cu}$ matrix composites are improved by adding reinforcement particles to the $\mathrm{Cu}$ matrix and increasing their volume or weight fractions (Singh et al., 2019; Shaik and Golla, 2020; Yin et al., 2020). However, due to the low electrical conductivity of reinforcement particles, the electrical conductivity of $\mathrm{Cu}$ matrix composites decreases. Satishkumar et al. produced $\mathrm{Cu}$ matrix composites by adding $\mathrm{WC}$ and $\mathrm{SiC}$ particles at the volume fractions ranging from 2.5 to $7.5 \%$ and suggested that the electrical conductivity of $\mathrm{Cu}-\mathrm{WC} / \mathrm{SiC}$ composites decreased as the amount of $\mathrm{WC} / \mathrm{SiC}$ particles increased due to the non-conducting effect of the reinforcement particles (Satishkumar et al., 2021). Kumar et al. studied the electrical and mechanical properties of $\mathrm{Cu}-\mathrm{TiB}_{2}$ composites and reported that adding $\mathrm{TiB}_{2}$ particles to the $\mathrm{Cu}$ matrix improved the strength of $\mathrm{Cu}-\mathrm{TiB}_{2}$ composites by up to $5 \mathrm{wt} . \% \mathrm{TiB}_{2}$, whereas the electrical conductivity of $\mathrm{Cu}-\mathrm{TiB}_{2}$ composites decreased as the weight fraction of $\mathrm{TiB}_{2}$ particles increased (Kumar et al., 2017). In a study on $\mathrm{Cu}$ matrix composites reinforced with $\mathrm{ZrO}_{2}$ particles, it was found that increasing the weight fraction of $\mathrm{ZrO}_{2}$ increased the hardness of the $\mathrm{Cu}-\mathrm{ZrO}_{2}$ composites while decreasing their electrical resistivity (Fan et al., 2019). The thermal conductivity of $\mathrm{Cu}$-matrix composites was found to behave similarly to electrical conductivity with regards to the effects of reinforcement volume or weight fractions (Wang et al., 2011).
$\mathrm{Cu}$ matrix composites are manufactured using a variety of methods such as casting and powder metallurgy (Sridhar et al., 2020). During the production of these conventional methods, porosity or undesirable interface reactions might occur, resulting in an additional decrease in the electrical and thermal conductivities and mechanical properties of $\mathrm{Cu}$ matrix composites. Microwave sintering and spark plasma sintering (SPS) outperform conventional methods in improving the properties of metal matrix composites. Microwave sintering has benefits such as enhanced diffusion and lower sintering temperatures (Oghbaei and Mirzaee, 2010), while SPS has advantages such as high densification and restriction of undesired reactions. (Cavaliere et al., 2019). Chmielewski et al. compared the effect of SPS with the influence of conventional hot pressing method on the thermal conductivity of $\mathrm{Cu}$ matrix composites reinforced with $5,10,15,20$, and 25 vol. $\%$ of SiC. It was found that while the thermal conductivities of $\mathrm{Cu}$ $\mathrm{SiC}$ composites manufactured by SPS and hot pressing methods decreased with an increase in the amount of $\mathrm{SiC}$ particles, the thermal conductivity of specimens produced by the SPS method was higher than that of specimens produced by the hot pressing method (Chmielewski et al., 2017). Ayyappadas et al. investigated the effects of microwave-assisted sintering versus conventional sintering on the electrical conductivity and hardness of $\mathrm{Cu}-\mathrm{SiC}$ composites $(2.5,5$, and 7.5 wt.\%) (Ayyappadas et al., 2017). It was reported that as the weight fraction of $\mathrm{SiC}$ particles increased, hardness increased but electrical conductivity decreased, and it was shown that the electrical conductivity and hardness of $\mathrm{Cu}-\mathrm{SiC}$ composites produced by microwave sintering were higher than those of conventional sintering specimens.

Nano-sized reinforcement particles are much more efficient in enhancing the mechanical properties of $\mathrm{Cu}$ matrix composites than micro-sized particles (Panda et al., 2014). However, reducing the size of the reinforcement particles lowers the electrical and thermal conductivities of $\mathrm{Cu}$ matrix composites (Kargul et al., 2018). While maintaining the positive effect of nanoparticles on mechanical properties, their negative effect on electrical and thermal conductivity can be eliminated by using reinforcement particles with higher conductivity. As compared to other types of reinforcement particles used in $\mathrm{Cu}$ matrix composites, lanthanum-based particles such as $\mathrm{LaB}_{6}$ and $\mathrm{La}_{2} \mathrm{O}_{3}$ have a high electrical conductivity. For this reason, recent studies on $\mathrm{Cu}$ matrix composites have focused on lanthanum-based 
particle reinforced $\mathrm{Cu}$ matrix composites (Cong et al., 2019; Solodkyi et al., 2020).

Considering the positive effects of nano-sized particles, $\mathrm{LaB}_{6}$ particle, and microwave sintering and SPS on the mechanical and electrical and thermal conductivities of $\mathrm{Cu}$ matrix composites, in this study, $\mathrm{Cu}$ matrix nanocomposites were produced by reinforcing with nano-sized $\mathrm{LaB}_{6}$ particles using microwave and SPS methods, and electrical, thermal, and mechanical properties of $\mathrm{Cu}-\mathrm{LaB}_{6}$ nanocomposites were investigated.

\section{Materials and methods}

Copper $(\mathrm{Cu})(33 \pm 7 \mu \mathrm{m})$ with a purity of $99.1 \%$ and lanthanum hexaboride $\left(\mathrm{LaB}_{6}\right)$ particles $(45 \mathrm{~nm})$ were used to produce $\mathrm{Cu}-\mathrm{LaB}_{6}$ nanocomposites.

Taking into consideration the amount of ceramic reinforcement particles in which the maximum (better) values of physical and mechanical properties of $\mathrm{Cu}$ matrix composites, such as electrical conductivity and compressive strength, were obtained in the studies found in the literature (Taha and Zawrah, 2017; Lakshmanan et al., 2019; Moustafa and Taha, 2021), the volume fraction of nano- $\mathrm{LaB}_{6}$ reinforcement particles in this study was determined to be $2 \%$. To distribute the nano$\mathrm{LaB}_{6}$ particles uniformly in $\mathrm{Cu}$ powders, a mechanical milling process was performed in a high-energy ball milling machine at a rotational speed of $350 \mathrm{rpm}$, a ball/powder ratio of 30:1, and an argon atmosphere, for 24 hours. Milling balls and jars were made of 304 stainless steel. Stearic acid was used as a process control agent to avoid excessive cold welding and bonding between powders and balls, and also to minimize powder agglomeration during the high-energy ball milling process.

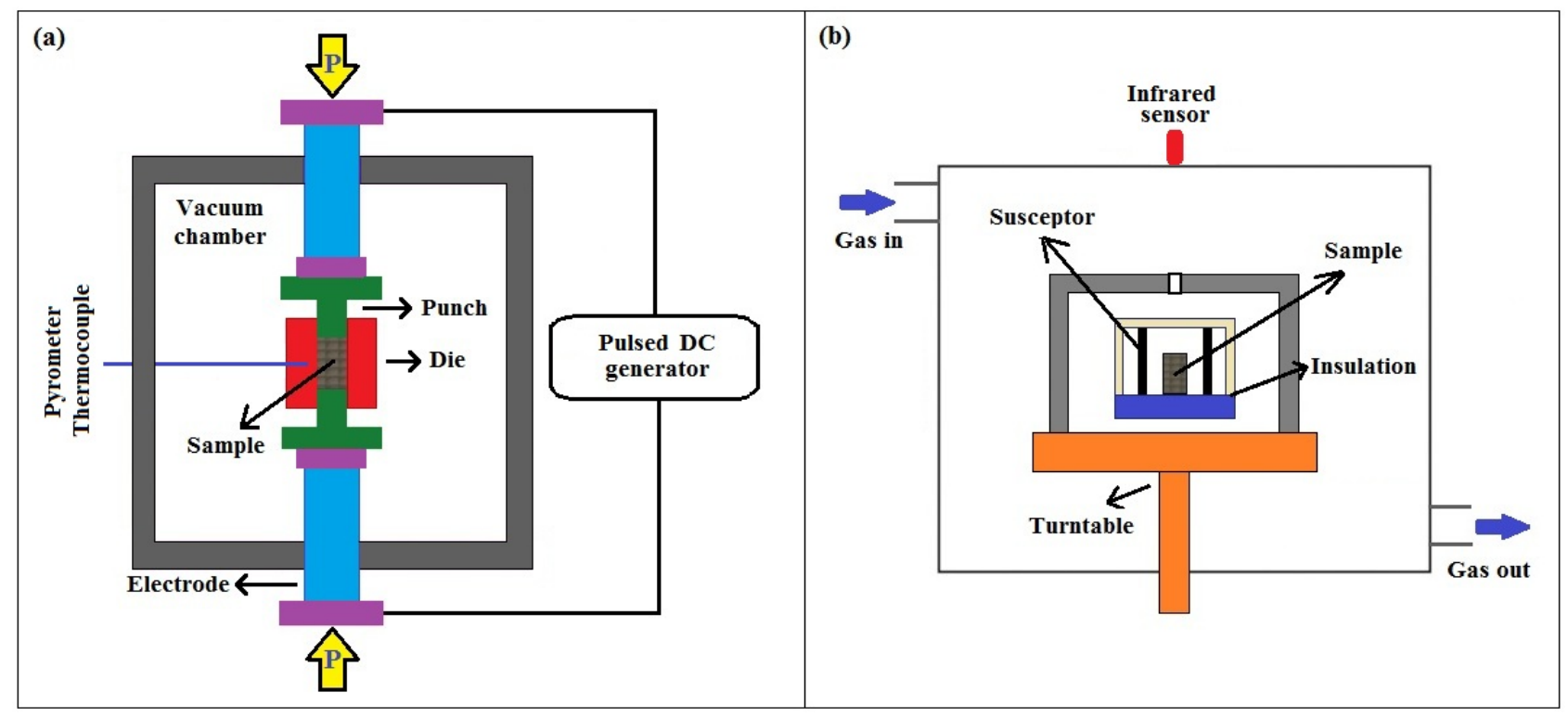

Figure 1. Schematic figures of (a) spark plasma sintering (SPS) and (b) microwave sintering (MS)

Mechanically milled $\mathrm{Cu}-\mathrm{LaB}_{6}$ powders were consolidated using microwave sintering (MS) and spark plasma sintering (SPS) to produce specimens with a diameter of about $13 \mathrm{~mm}$ and a height of about $25 \mathrm{~mm}$ (Figure 1). According to a literature review (Ngai et al., 2013; Ayyappadas et al., 2017; Sathish et al., 2019; Pellizzari and Cipolloni, 2020), in this study, the optimum values for the production parameters in MS and SPS methods used to produce ceramic particle-reinforced $\mathrm{Cu}$ matrix composites were determined, and these values were taken as high as possible in order to achieve higher density, which leads to better mechanical and physical properties such as compressive strength and electrical conductivity, as well as to avoid excessive grain growth, which has a negative effect on the properties of the materials. Prior to the microwave sintering process, powders were pressed at a pressure of $400 \mathrm{MPa}$ in a steel mold. The compacted specimens were sintered in a microwave furnace $(2.45 \mathrm{GHz})$ to 900 ${ }^{\circ} \mathrm{C}$ at a heating rate of $25{ }^{\circ} \mathrm{C} / \mathrm{min}$, a holding time of $30 \mathrm{~min}$, and a $95 \% \mathrm{~N}_{2}-5 \% \mathrm{H}_{2}$ atmosphere. $\mathrm{SiC}$ susceptor (microwave-absorbing element) was used to assist heating and sintering of the compacted specimens. Prior to the SPS process, powders were pressed at a pressure of $40 \mathrm{MPa}$ in a steel mold. Because of the high number, large, and non-uniform distribution of the voids between the powders, loose powders poured into the die cavity 
cause the current not to be homogeneously distributed in the powder sample throughout the SPS process, resulting in a temperature gradient during discharging. Inhomogeneous temperature distribution can also cause local discrepancies in Joule heating (Leich et al., 2020). However, in a compact structure formed by pre-compaction, this can make discharging and Joule heating more efficient during the SPS process since the contact points and areas of powders with each other will increase (Balice et al., 2021). For all of these reasons, in this study, pre-compaction was applied to the powders in order to make the powders more compact and then perform more effectively in the SPS process. Following the pre-compaction process of the powders, the SPS process was applied to the pre-compacted powders in a graphite die, at a compaction pressure of $50 \mathrm{MPa}$, a temperature of $900{ }^{\circ} \mathrm{C}$, and a heating rate of $100^{\circ} \mathrm{C} / \mathrm{min}$ under vacuum for $5 \mathrm{~min}$. After dwelling at maximum temperatures for a set period of time in the SPS and MS processes, the specimens were cooled at a rate of $25^{\circ} \mathrm{C} / \mathrm{min}$.

Since pores and voids in the microstructure have a significant impact on the electrical and thermal conductivities, and the mechanical properties of the materials, both experimental and theoretical densities of the specimens were determined in this study. The experimental density $(\rho)$ of specimens was measured according to Archimedes' principle using a high accuracy balancer $( \pm 0.01 \mathrm{mg})$. The theoretical density was calculated using the following equation: $\rho_{\mathrm{th}}=\mathrm{V}_{\mathrm{m}} \cdot \rho_{\mathrm{m}}+\mathrm{V}_{\mathrm{r}} \cdot \rho_{\mathrm{r}}$ (where $\mathrm{V}_{\mathrm{m}}$ and $V_{r}$ are the volume fractions of the matrix and the reinforcement particles, respectively, and $\rho_{\mathrm{m}}$ and $\rho_{\mathrm{r}}$ are the densities of the matrix and the reinforcement particles, respectively). Theoretical densities of $\mathrm{Cu}$ and $\mathrm{LaB}_{6}$ were assumed to be 8.96 $\mathrm{g} / \mathrm{cm}^{3}$ and $4.72 \mathrm{~g} / \mathrm{cm}^{3}$, respectively. The porosity percentage of the specimens was calculated as follows: Porosity $(\%)=\left(\rho_{\text {th }}-\rho\right) / \rho_{\text {th }}$. The thermal conductivity $(\lambda)$ of the specimens was determined using the following equation: $\lambda=\alpha \cdot \rho \cdot \mathrm{C}_{\mathrm{p}}$, where $\alpha$ is the thermal diffusivity, $\rho$ is the density, and $C_{p}$ is the specific heat capacity. $\alpha$ and $C_{p}$ were measured using a laser flash apparatus (NETZSCH-LFA 467 HyperFlash). The electrical resistivity of the specimens was measured by utilizing a high-precision micro-ohmmeter (Omega-CL8400). The measured electrical resistivity was then converted into the international annealed copper standard conductivity (\%IACS) unit. The thermal conductivity, electrical conductivity, and density of the specimens were measured at room temperature. Measurements for electrical and thermal conductivities were repeated five times for each specimen to obtain a more accurate result, and an average value was taken. Hardness testing of the specimens was conducted using a Vickers hardness tester (Shimadzu HMV2) with a load of $0.3 \mathrm{kgf}(2.942 \mathrm{~N})$ for a dwell time of $10 \mathrm{~s}$. Compression tests of the specimens were conducted at room temperature at a strain rate of $0.005 \mathrm{~min}^{-1}$ (Shimadzu AG-IS-100 kN). The elemental analyses of the specimens were determined by XRD (X-ray diffraction) and XPS (X-ray photoelectron spectroscopy) analysis. SEM (scanning electron microscopy) was used to show the microstructures and the fracture surfaces of the specimens.

\section{Results and discussion}

\subsection{Microstructure}

Figure 2 shows the microstructures of $\mathrm{Cu}-\mathrm{LaB}_{6}$ nanocomposites produced using microwave sintering (MS) and spark plasma sintering (SPS) processes. As seen in Figure 2, nano $\mathrm{Cu}-\mathrm{LaB}_{6}$ reinforcement particles were distributed uniformly in the copper matrix through the high-energy ball milling process. XRD analysis of a $\mathrm{Cu}-\mathrm{LaB}_{6}$ nanocomposite specimen is shown in Figure 3. Three peaks were detected at $2 \theta$ values of $43.7^{\circ}$, $50.8^{\circ}$, and $74.4^{\circ}$ degrees corresponding to (111), (200), and (220) of copper, respectively, while two peaks were identified at $2 \theta$ values of $20.7^{\circ}$ and $30.2^{\circ}$ degrees corresponding to (100) and (110) of $\mathrm{LaB}_{6}$, respectively.

Table 1 shows the elemental compositions of unreinforced $\mathrm{Cu}$ and $\mathrm{Cu}-\mathrm{LaB}_{6}$ nanocomposites produced using MS and SPS methods. In addition to the elements $\mathrm{Cu}, \mathrm{La}$, and $\mathrm{B}$, XPS analyses revealed the elements $\mathrm{C}$ and $\mathrm{O}$ in relatively considerable amounts and $\mathrm{Fe}, \mathrm{Cr}$, and $\mathrm{Ni}$ in trace amounts in the specimens. It can be attributed to the following reasons. The elements of $\mathrm{C}, \mathrm{Fe}, \mathrm{Cr}$, and Ni may have contaminated the powders during the high-energy ball milling process due to jar and ball wear. Because of the abrasive impact of reinforcement particles, this may have been more active in $\mathrm{Cu}-\mathrm{LaB}_{6}$ nanocomposites; therefore, the amount of these contaminants was higher in $\mathrm{Cu}$ $\mathrm{LaB}_{6}$ nanocomposites than in unreinforced $\mathrm{Cu}$, as seen in Table 1. It should be noted that stearic acid, which was used in the high-energy ball milling process, may have caused a significant amount of $\mathrm{C}$ to be found in the specimens. The $\mathrm{O}$ contamination found in the specimens may have been resulted from the oxidation of powders before and during the manufacturing processes (particularly the high-energy ball milling process). 
A higher amount of $\mathrm{O}$ in the specimens produced using the MS method, which can be attributed to the longer processing time in the MS method compared to the SPS method. These contaminants may have an influence on material properties such as electrical conductivity (Ayyapadas et al., 2017; Degroh and Balachandran, 2018).
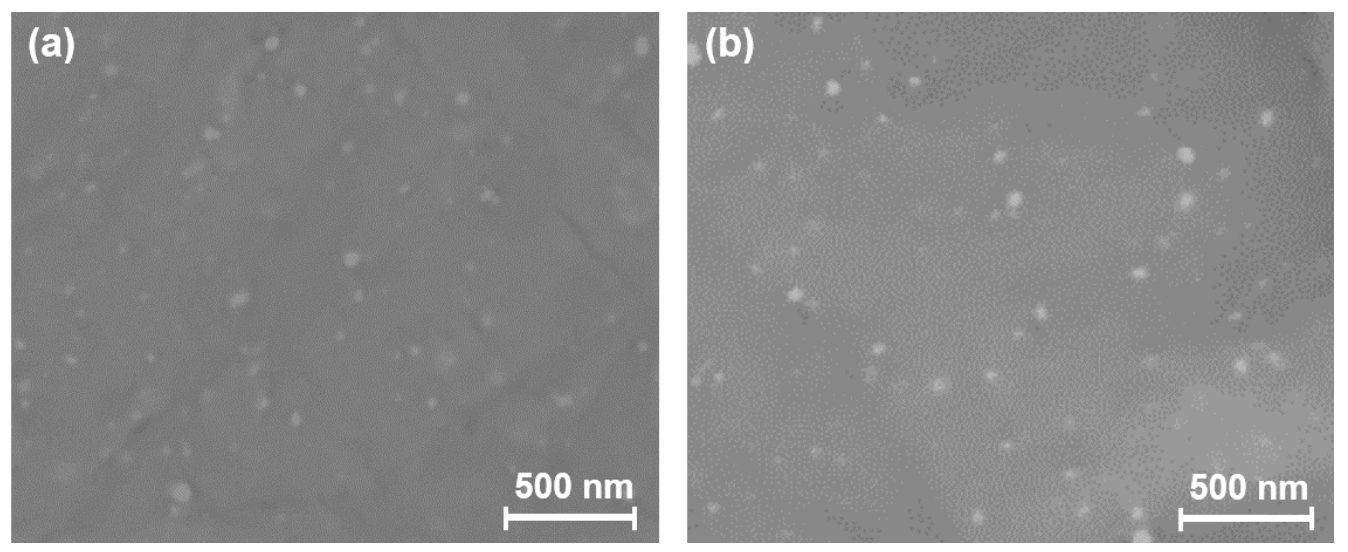

Figure 2. SEM images of $\mathrm{Cu}-\mathrm{LaB}_{6}$ nanocomposites produced using (a) microwave sintering (MS) and (b) spark plasma sintering (SPS) processes

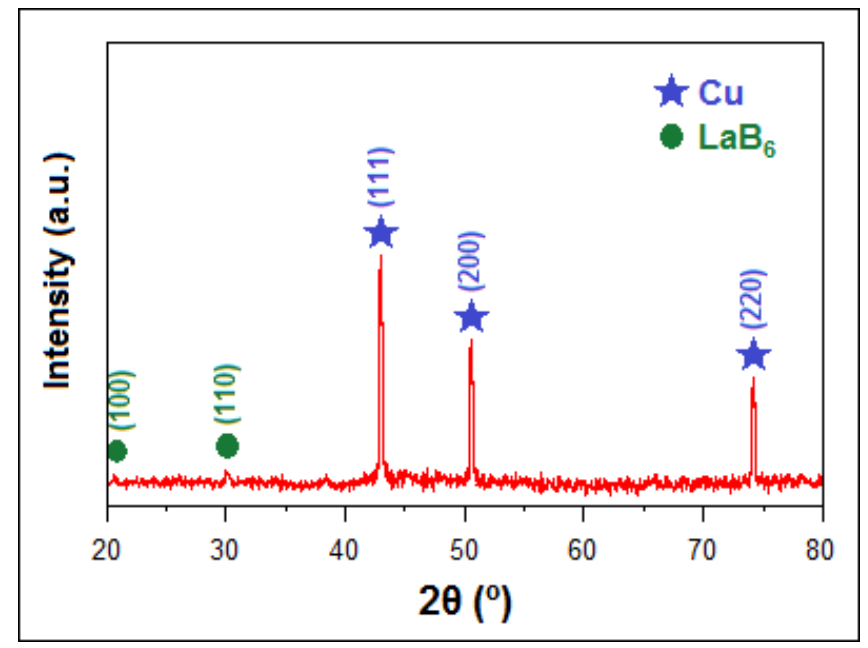

Figure 3. $\mathrm{XRD}$ analysis of $\mathrm{Cu}-\mathrm{LaB}_{6}$ nanocomposite

Table 1. XPS elemental compositions (wt.\%) of unreinforced $\mathrm{Cu}$ and $\mathrm{Cu}-\mathrm{LaB}_{6}$ nanocomposites produced using MS and SPS

\begin{tabular}{lcccccccc}
\hline & \multicolumn{7}{c}{ Weight (\%) } \\
\hline & $\mathbf{C u}$ & La & B & C & O & Fe & Cr & Ni \\
Microwave sintering & & & & & & & & \\
$\mathrm{Cu}$ & Bal. & - & - & 0.10 & 0.05 & $<0.01$ & $<0.01$ & $<0.01$ \\
$\mathrm{Cu}-\mathrm{LaB}_{6}$ & Bal. & 0.69 & 0.32 & 0.09 & 0.04 & $<0.01$ & $<0.01$ & $<0.01$ \\
Spark plasma sintering & & & & & & & & \\
$\mathrm{Cu}$ & Bal. & - & - & 0.08 & 0.03 & $<0.01$ & $<0.01$ & $<0.01$ \\
$\mathrm{Cu}-\mathrm{LaB}_{6}$ & Bal. & 0.71 & 0.33 & 0.09 & 0.03 & $<0.01$ & $<0.01$ & $<0.01$ \\
\hline
\end{tabular}

Compared to MS and SPS processes with each other, while the only temperature is efficient on pre-compacted specimens during MS, the simultaneous application of temperature and pressure in the SPS process results in higher density. For all of these reasons, the relative density 
of unreinforced $\mathrm{Cu}$ and $\mathrm{Cu}-\mathrm{LaB}_{6}$ nanocomposite produced by SPS was higher than that of manufactured through the MS process (Figure 4a); in other words, the porosity level in the specimens produced by SPS was lower as seen in Figure $4 b$.

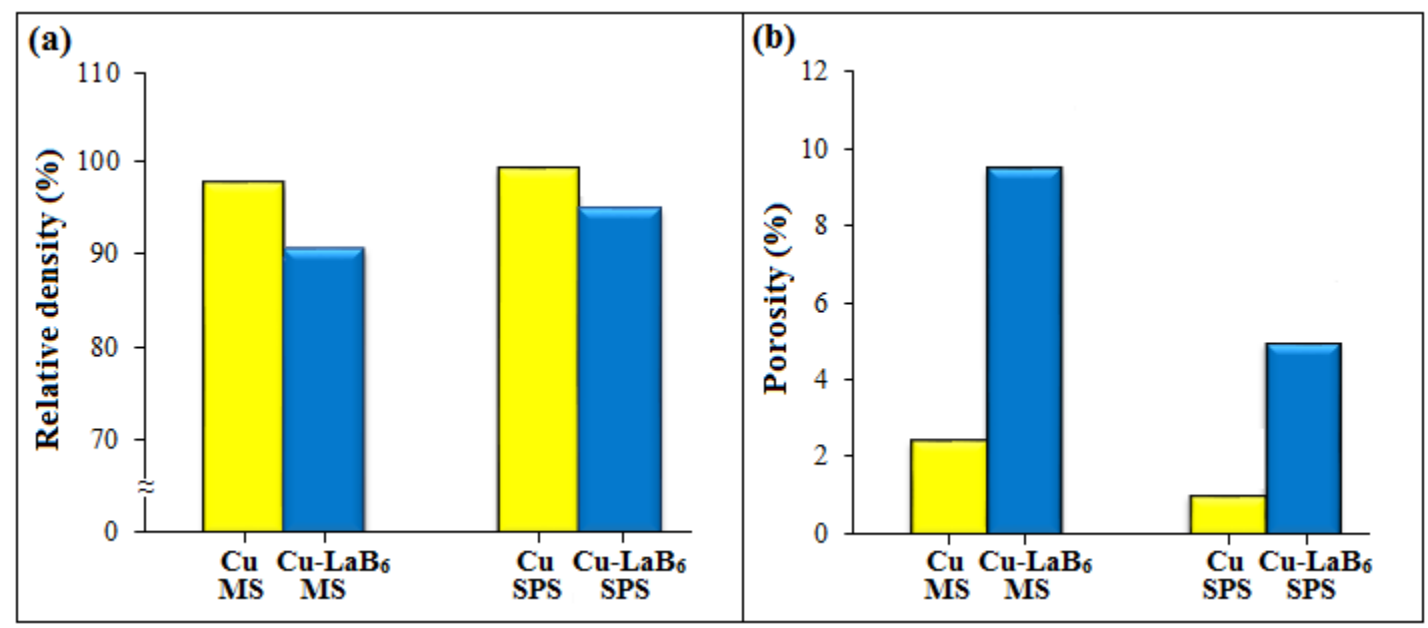

Figure 4. Relative densities and porosities of unreinforced $\mathrm{Cu}$ and $\mathrm{Cu}-\mathrm{LaB}_{6}$ nanocomposites produced using MS and SPS

\subsection{Electrical conductivity}

Figure 5 shows the electrical conductivities of unreinforced $\mathrm{Cu}$ and $\mathrm{Cu}-\mathrm{LaB}_{6}$ nanocomposites. The electrical conductivities of nanocomposites produced by MS and SPS were $20 \%$ and $13 \%$ lower, respectively, than those of unreinforced $\mathrm{Cu}$ manufactured using MS and SPS. The electrical conductivity of unreinforced $\mathrm{Cu}$ produced through SPS was $8 \%$ higher than that of the specimen produced via MS. Similar behaviour was observed in $\mathrm{Cu}-\mathrm{LaB}_{6}$ nanocomposites. The electrical conductivity of the $\mathrm{Cu}-\mathrm{LaB}_{6}$ nanocomposite manufactured using the SPS method was $14 \%$ higher than that of the $\mathrm{Cu}-\mathrm{LaB}_{6}$ nanocomposite produced through MS.

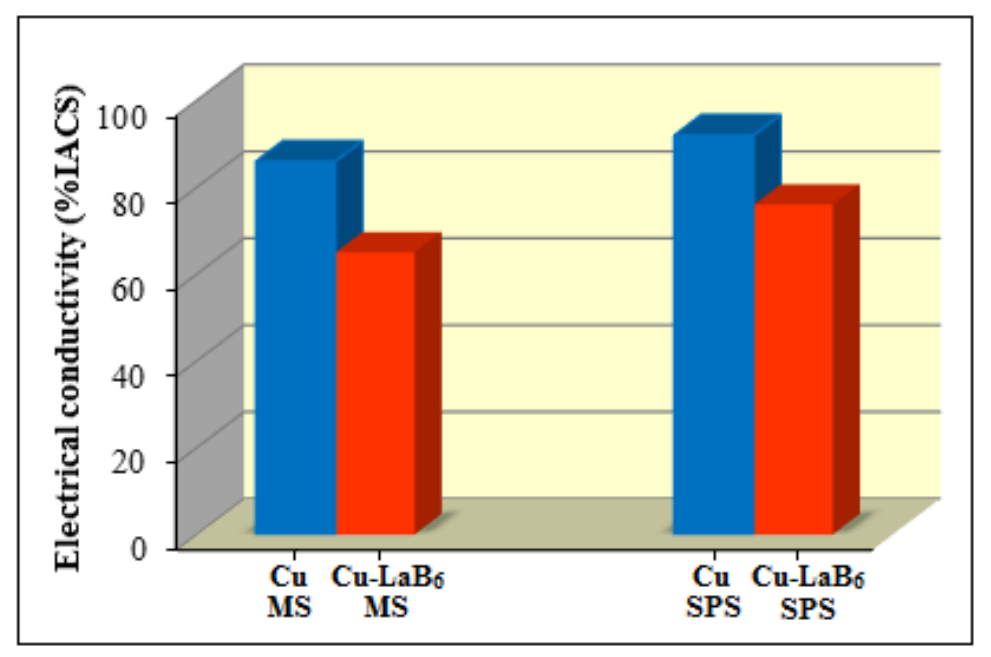

Figure 5. Electrical conductivities of unreinforced $\mathrm{Cu}$ and $\mathrm{Cu}-\mathrm{LaB}_{6}$ nanocomposites produced by MS and SPS

Electrical conductivity in a metallic material is determined by the mobility of charge carriers such as electrons, which is highly influenced by pores and voids in the microstructure. Pore and void can restrict the movement of charge carriers. In SPS, the DC pulse discharge generates spark plasma, spark impact pressure, Joule heating, and an electrical field diffusion (Suárez et al., 2013). The formation of plasma during SPS has a direct impact on powder sintering. Spark discharge occurs in the space between the powders, which increases the diffusion rate due to the melting formed on powder surfaces, resulting in high density in SPS method (Saheb, 2013). It should also be noted that, as 
mentioned above, depending on the production method, the porosity level in the specimens produced by SPS was lower than that in the specimens manufactured through MS (Figure 4b), resulting in higher electrical conductivity in the specimens produced using the SPS (Figure 5).

The electrical conductivity of $\mathrm{Cu}-\mathrm{LaB}_{6}$ nanocomposites was lower than that of unreinforced $\mathrm{Cu}$, as seen in Figure 5. It can be due to a number of factors caused by the addition of reinforcement particles. First, ceramic-based reinforcement particles such as $\mathrm{LaB}_{6}$ have low electrical conductivity than metals such as $\mathrm{Cu}$. Second, hard reinforcement particles resist the densification of powders during the compaction process. Third, if a mechanical milling process is applied to the powders prior to MS and SPS, this process will harden the powders, which leads to retarding the compaction of powders during pressing. The second and third factors result in a reduction in electrical conductivity by causing pores to form in the microstructure. In addition to these factors, elements found in copper metal, such as $\mathrm{C}$ and $\mathrm{O}$, may tend to enhance the scattering rate of conducting electrons, resulting in a reduction in the electrical conductivity of the copper ( $\mathrm{Li}$ et al., 2016; Ayyapadas et al., 2017; Degroh and Balachandran, 2018). Although the amount of Fe, $\mathrm{Cr}$, and $\mathrm{Ni}$ contaminants in this study was insufficient to alter the electrical conductivity, C and $\mathrm{O}$ may have had a modest effect on the reduction of electrical resistance. Furthermore, as seen in Table 1, the amount of $\mathrm{O}$ in the specimens produced using the MS method was higher than that in the specimens manufactured through the SPS method due to the longer processing time in the MS method. When compared to the SPS method, the relatively high amount of contaminants formed in the specimens produced by the MS method may have contributed to the reduction in electrical conductivity of the specimens. For all of these reasons (ceramic $\mathrm{LaB}_{6}$ particles, pores, and contaminations), the electrical conductivity of $\mathrm{Cu}-\mathrm{LaB}_{6}$ nanocomposite produced using the MS method was lower than that of the SPS method.

\subsection{Thermal conductivity}

Thermal conductivities of unreinforced $\mathrm{Cu}$ and $\mathrm{Cu}$ $\mathrm{LaB}_{6}$ nanocomposites are shown in Figure $6 . \mathrm{Cu}-$ $\mathrm{LaB}_{6}$ nanocomposites had lower thermal conductivity than unreinforced $\mathrm{Cu}$. Nano $\mathrm{LaB}_{6}$ particles reduced the thermal conductivity of the specimens manufactured through MS and SPS as compared to that of unreinforced $\mathrm{Cu}$ specimens produced using the same processes. Heat in ceramics is only conducted by phonons while thermal conduction in metals is provided by both phonons and free electrons. This is one of the reasons why the thermal conductivity of $\mathrm{LaB}_{6}$ particle reinforced nanocomposites was lower than that of unreinforced $\mathrm{Cu}$ specimens.

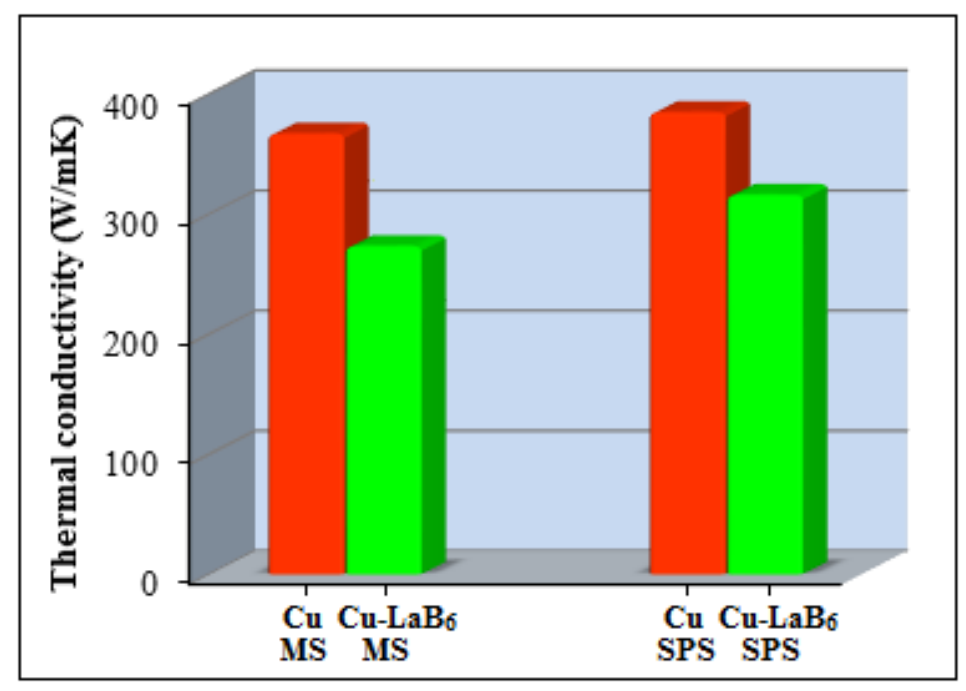

Figure 6. Thermal conductivities of unreinforced $\mathrm{Cu}$ and $\mathrm{Cu}-\mathrm{LaB}_{6}$ nanocomposites produced by MS and SPS

Unreinforced $\mathrm{Cu}$ and $\mathrm{Cu}-\mathrm{LaB}_{6}$ nanocomposites produced by SPS had higher thermal conductivity than those manufactured through MS, which could be attributed to lower porosity in the specimens produced by SPS. It should be also noted that in addition to negative effects of pore and reinforcement particles with low thermal conductivity, the interface between matrix and reinforcement is another factor that resists heat flow due to the scattering of phonons and electrons 
in this region. Thermal conductivity of ceramicparticle reinforced metal matrix composites such as $\mathrm{Cu}-\mathrm{LaB}_{6}$ composite can further decrease as a result of these interfaces, which can be more important in nano-particle reinforced composites due to the greater number of nano-particle interfaces.

The Wiedemann-Franz law given in Equation (1) describes the relationship between the thermal conductivity $(\lambda)$ and the electrical conductivity $(\sigma)$ of a material containing freely moving electrons.

$\frac{\lambda}{\sigma}=L T$

where $L$ is the Lorenz number and $T$ is the temperature. By taking into account phonons, which transport thermal energy but not electrical energy, the relationship between $\lambda$ and $\sigma$ can be altered by using a constant nonmetallic part (k) of the thermal conductivity as follows (Raab et al., 2016):

$$
\lambda=\mathrm{k}+\sigma L T
$$

However, as the porosity in the specimens increases, the reliability of Equation (2) decreases. The amount of porosity in metal matrix composites varies depending on the manufacturing process and also the reinforcements used and their proportions, particularly nano-sized particles. Ceramic-based reinforcement particles have very low conductivity and may cause an increase in porosity, which results in a reduction in conductivity. In this study, Equation (2) has been modified to account for the volume fraction of reinforcement particles and the porosity levels in the composite specimens in order to determine the relationship between thermal conductivity and electrical conductivity in particlereinforced metal matrix composites as follows:

$\lambda=(1-V-P)(\mathrm{k}+\sigma L T)$

where $V$ is the volume fraction of reinforcement particles and $P$ is the fraction of the pores.
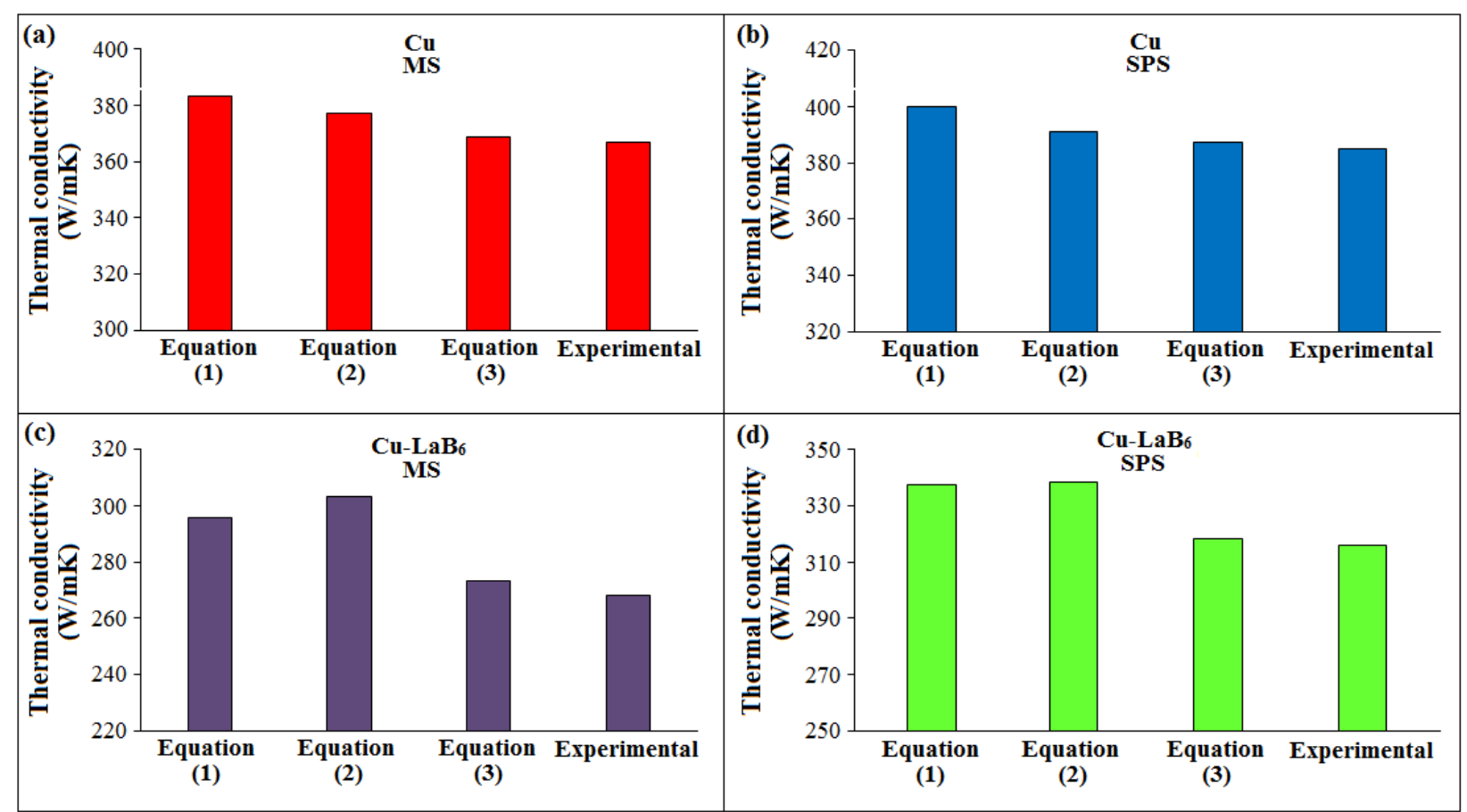

Figure 7. Prediction of thermal conductivities from experimental electrical conductivities with different approaches (equations) and comparison with experimental thermal conductivities of (a) and (b) unreinforced $\mathrm{Cu}$ produced by MS and SPS respectively, and (c) and (d) $\mathrm{Cu}-\mathrm{LaB}_{6}$ nanocomposites manufactured through MS and SPS, respectively.

Figure 7 shows thermal conductivities calculated from experimental electrical conductivities using various methods (Equations (1)-(3)). The constant $\mathrm{k}$ was assumed to be $53.1 \mathrm{~W} / \mathrm{mK}$ in Equations (2) and (3) by using the linear fitted value found in a study (Raab et al., 2016). The Lorenz numbers were $2.07 \times 10^{-8} \mathrm{~W} \Omega / \mathrm{K}^{2}$ (Raab et al., 2016) and
$2.45 \times 10^{-8} \mathrm{~W} \Omega / \mathrm{K}^{2}$ (White and Tainsh, 1960) for Equation (1) and Equations (2) and (3), respectively. In comparison to Equations (1) and (2), Equation (3) developed for particle-reinforced metal matrix composites predicted results that were very close to the experimental results, as seen in Figure 7 . These findings indicate that the negative 
effects of porosity and reinforcement particle volume ratios are highly effective on the thermal conductivity of particle-reinforced metal matrix composites such as $\mathrm{Cu}-\mathrm{LaB}_{6}$, and that these factors must be considered when calculating (predicting) thermal conductivity from experimental electrical conductivity.

\subsection{Hardness and compressive strength}

The hardness values of $\mathrm{Cu}-\mathrm{LaB}_{6}$ nanocomposites produced using MS and SPS were $34 \%$ and $49 \%$ higher, respectively than that of unreinforced $\mathrm{Cu}$ manufactured with MS and SPS (Figure 8). Reinforcement particles have significant effects on the hardening of the metal matrix to which they are added, both directly and indirectly. Firstly, the hardness of $\mathrm{LaB}_{6}$ particles is greater than that of $\mathrm{Cu}$. Secondly, reinforcement particles in metal matrix composites inhibit the movement of dislocations in the matrix (Lin et al., 2021). Thirdly, dislocation density increases due to the mismatch of thermal expansion coefficients between matrix and reinforcement particles (Matvienko et al., 2021), resulting in additional inhibition of dislocation movements. For all of these factors, $\mathrm{Cu}-\mathrm{LaB}_{6}$ nanocomposites were harder than unreinforced $\mathrm{Cu}$.

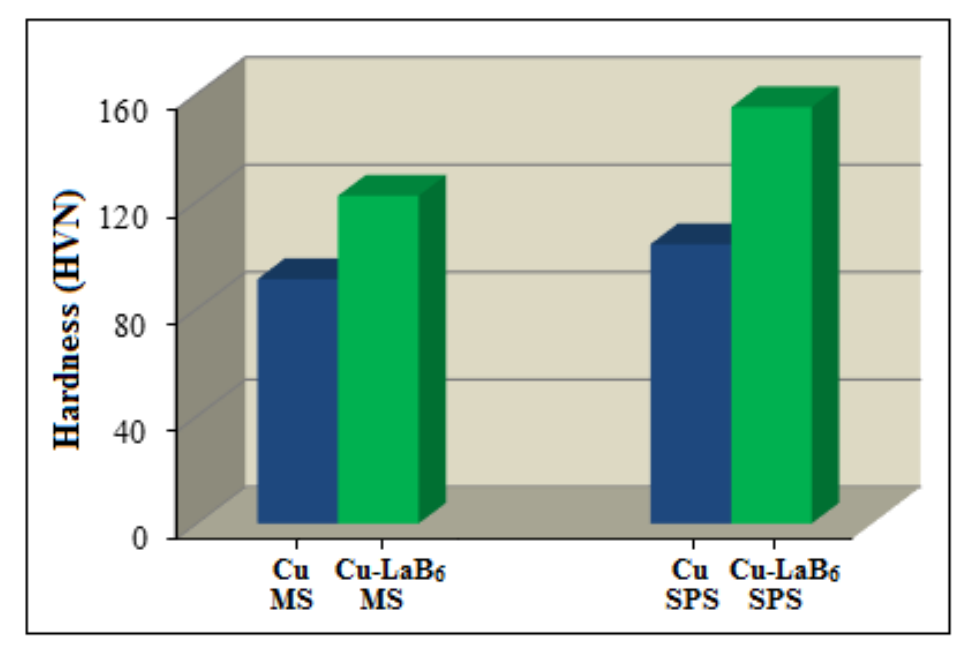

Figure 8. Hardness of unreinforced $\mathrm{Cu}$ and $\mathrm{Cu}-\mathrm{LaB}_{6}$ nanocomposites manufactured through MS and SPS

The hardness of unreinforced $\mathrm{Cu}$ and $\mathrm{Cu}-\mathrm{LaB}_{6}$ nanocomposite produced by MS was lower than that produced by SPS. This is due to to the higher porosity of specimens manufactured through the SPS compared to those produced with the MS because porosity has a negative influence on the hardness of particle-reinforced metal matrix composites (Hossein et al., 2014).

Figure 9 shows the compressive strengths of unreinforced $\mathrm{Cu}$ and $\mathrm{Cu}-\mathrm{LaB}_{6}$ nanocomposites. The addition of reinforcement particles into a metal matrix improves mechanical properties such as compressive strength due to the following strengthening mechanisms (Ye et al., 2018): (I) load-bearing effect of reinforcement particles, (II) grain boundary strengthening (Hall-Petch), (III) Orowan strengthening, and (IV) enhanced dislocation-based strengthening mechanisms resulted from the mismatches of thermal expansion coefficients and elastic modulus between the reinforcement particles and the metal matrix. The addition of nano $\mathrm{LaB}_{6}$ particles in the $\mathrm{Cu}$ matrix increased the compressive strength of $\mathrm{Cu}-\mathrm{LaB}_{6}$ nanocomposite produced by SPS by $38 \%$ as compared to unreinforced $\mathrm{Cu}$ specimen produced using the same method (Figure 9). Nano $\mathrm{LaB}_{6}$ particle reinforced $\mathrm{Cu}_{-}-\mathrm{LaB}_{6}$ nanocomposite manufactured through MS had a 29\% higher compressive strength than unreinforced $\mathrm{Cu}$ specimens produced by MS. These findings clearly showed that nano $\mathrm{LaB}_{6}$ particles and SPS had a strong influence in improving the compressive strength of $\mathrm{Cu}$ matrix nanocomposites. Porosity, on the other hand, had a negative effect on the compressive strength of $\mathrm{Cu}-\mathrm{LaB}_{6}$ nanocomposites, depending on the manufacturing process, with a greater negative influence in the $\mathrm{Cu}-\mathrm{LaB}_{6}$ nanocomposite produced using the MS process. As seen in Figure 10, the pores formed in the $\mathrm{Cu}-\mathrm{LaB}_{6}$ nanocomposite manufactured via MS were more numerous and greater than those formed in the $\mathrm{Cu}-$ $\mathrm{LaB}_{6}$ nanocomposite specimen produced with SPS, resulting in lower compressive strength. 


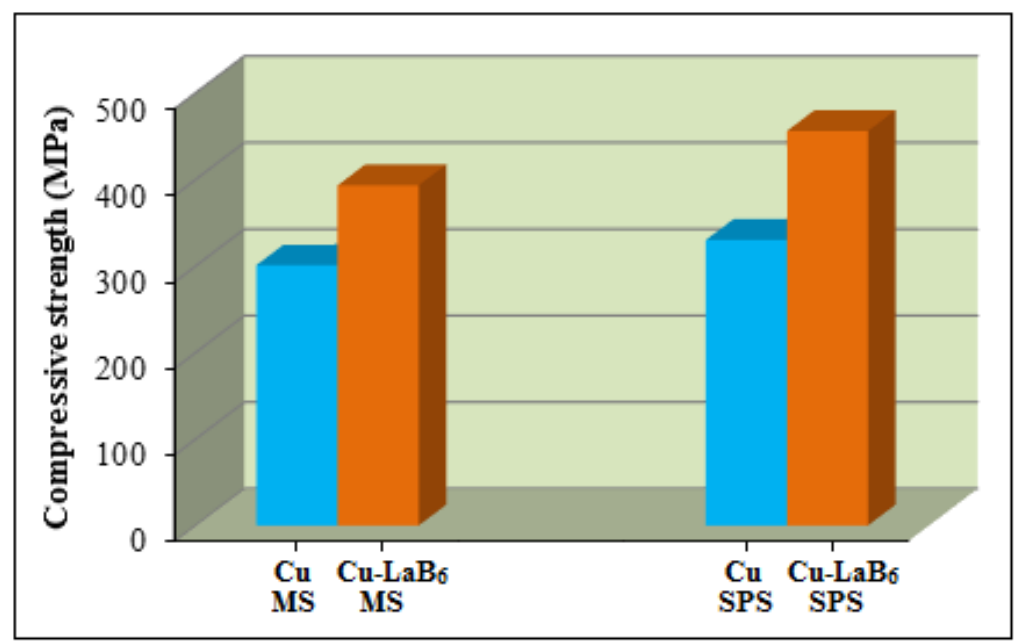

Figure 9. Compressive strengths of unreinforced $\mathrm{Cu}$ and $\mathrm{Cu}-\mathrm{LaB}_{6}$ nanocomposites produced by MS and SPS
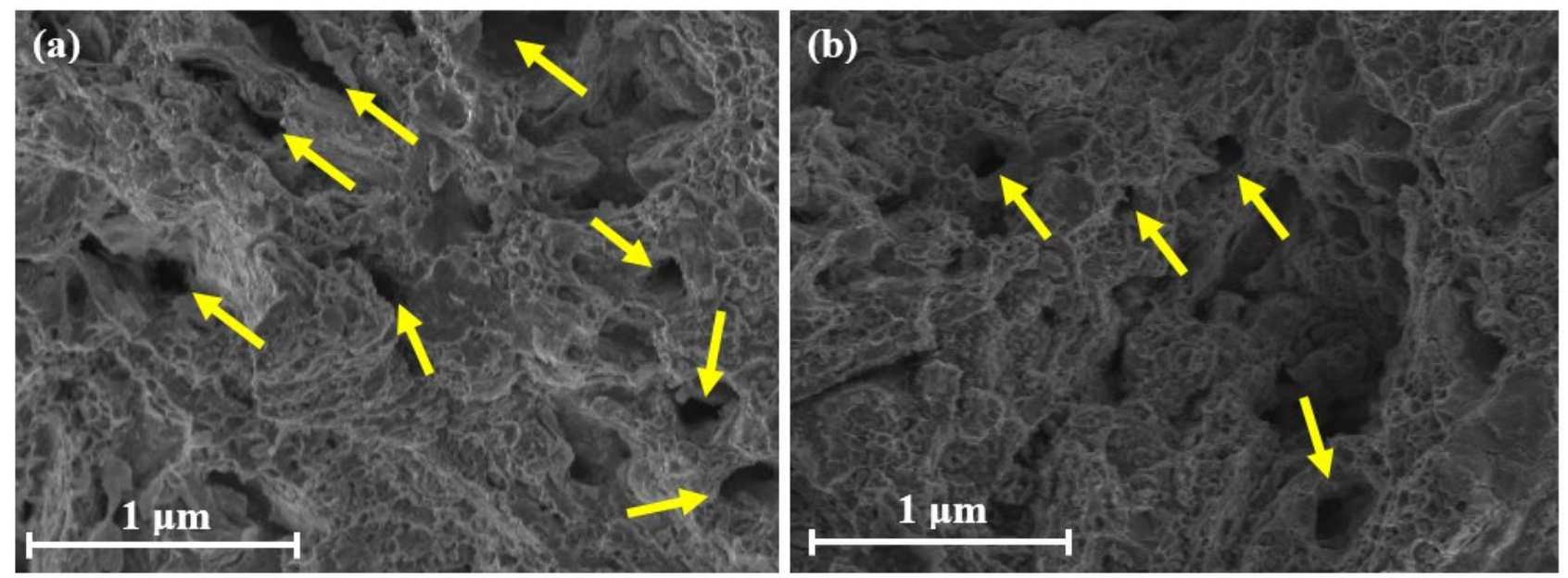

Figure 10. SEM images of fracture surfaces of $\mathrm{Cu}-\mathrm{LaB}_{6}$ nanocomposites produced by (a) MS and (b) SPS

\section{Conclusions}

Copper was reinforced with nano $\mathrm{LaB}_{6}$ particles using microwave sintering and spark plasma sintering to produce $\mathrm{Cu}-\mathrm{LaB}_{6}$ nanocomposites, and the electrical, thermal, and mechanical properties of unreinforced $\mathrm{Cu}$ and $\mathrm{Cu}-\mathrm{LaB}_{6}$ nanocomposites were investigated. The nano $\mathrm{LaB}_{6}$ particles reduced the electrical conductivities of $\mathrm{Cu}$. $\mathrm{Cu}_{-} \mathrm{LaB}_{6}$ nanocomposites produced with MS and SPS had lower electrical conductivity than unreinforced $\mathrm{Cu}$ by $20 \%$ and $13 \%$, respectively. Similarly, $\mathrm{Cu}-\mathrm{LaB}_{6}$ nanocomposites had lower thermal conductivity than unreinforced $\mathrm{Cu}$. The electrical and thermal conductivities of $\mathrm{Cu}-\mathrm{LaB}_{6}$ nanocomposite manufactured through SPS were higher than those of $\mathrm{Cu}-\mathrm{LaB}_{6}$ nanocomposite produced using $\mathrm{MS}$ since lower porosity was achieved in production with the SPS process. To calculate the thermal conductivity of nanocomposites from their electrical conductivity, an equation that takes particle volume ratio and porosity into account was developed. The predicted thermal conductivities of $\mathrm{Cu}-\mathrm{LaB}_{6}$ nanocomposites were very close to the experimental results. $\mathrm{Cu}-\mathrm{LaB}_{6}$ nanocomposites produced via MS and SPS had much higher hardness by $34 \%$ and $49 \%$, respectively, compared to those of unreinforced $\mathrm{Cu}$ manufactured using the same processes. The compressive strength of $\mathrm{Cu}$ $\mathrm{LaB}_{6}$ nanocomposites produced by MS and SPS were $29 \%$ and $38 \%$ higher than those of unreinforced $\mathrm{Cu}$ manufactured through $\mathrm{MS}$ and SPS. SPS process had a greater positive effect on the electrical, thermal, hardness, and compressive strength of $\mathrm{Cu}-\mathrm{LaB}_{6}$ nanocomposites than $\mathrm{MS}$ process. In conclusion, despite the fact that nano $\mathrm{LaB}_{6}$ reinforcement particles reduced the electrical and thermal conductivities of $\mathrm{Cu}, \mathrm{Cu}-\mathrm{LaB}_{6}$ nanocomposite having high hardness and compressive strength were produced by combining the positive influences of nano $\mathrm{LaB}_{6}$ reinforcement particles and the SPS process. 


\section{References}

Afzal, S. R. and Harish, S. (2020). Synthesis and characterization of titanium carbide reinforced copper based metal matrix composite. International Research Journal of Engineering and Technology, 7(7), 2451-2457.

Ayyappadas, C., Annamalai, A. R., Agrawal, D. K. and Muthuchamy, A. (2017). Conventional and microwave assisted sintering of copper-silicon carbide metal matrix composites: a comparison. Metallurgical Research \& Technology, 114(5), 506(1-10).

https://doi.org/10.1051/metal/2017033

Balice, L., Cologna, M., Audubert, F. and Hazemann, J. L. (2021). Densification mechanisms of $\mathrm{UO}_{2}$ consolidated by spark plasma sintering. Journal of the European Ceramic Society, 41(1), 719728.https://doi.org/10.1016/j.jeurceramsoc. 2020 .07 .002

Bian, Y., Ni, J., Wang, C., Zhen, J., Hao, H., Kong, X., Chen, H., Li, J., Li, X., Jia, Z., Luo, W. and Chen, Z. (2021). Microstructure and wear characteristics of in-situ micro/nanoscale niobium carbide reinforced copper composites fabricated through powder metallurgy. Materials Characterization, 172(110847), 1-14. https://doi.org/10.1016/j.matchar.2020.110847

Cavaliere, P., Sadeghi, B. and Shabani, A. (2019). Spark plasma sintering: Process fundamentals. P. Cavaliere (Ed.) Spark Plasma Sintering of Materials Advances in Processing and Applications (pp. 3-20). Cham: Springer Nature. https://doi.org/10.1007/978-3-030-05327-7

Chmielewski, M., Pietrzak, K., Strojny-Nędza, A., Kaszyca, K., Zybała, R., Bazarnik, P., Lewandowska, M. and Nosewicz, S. (2017). Microstructure and thermal properties of $\mathrm{Cu}-\mathrm{SiC}$ composite materials depending on the sintering technique. Science of Sintering, 49, 11-22. https://doi.org/10.2298/SOS1701011C

Cong, D., Huimin, L., Shan, F., Yuan, Q., Qilong, H. and Jiachen, J. (2019). Effect of $\mathrm{La}_{2} \mathrm{O}_{3}$ addition on copper matrix composites reinforced with $\mathrm{Al}_{2} \mathrm{O}_{3}$ ceramic particles. Materials Research Express, 6(10), https://doi.org/10.1088/2053-1591/ab3eff

Degroh, H. C. and Balachandran, U. B. (2018). Conductivity of copper-carbon covetic composite. NASA STI Program, 219790 (pp 11).

Dias, M., Pinhão, N., Faustino, R., Martins, R. M. S., Ramos, A. S., Vieira, M. T., Correia, J. B., Camacho, E.., Fernandes, F. M. B., Nunes, B., Almeida, A., Mardolcar, U. V. and Alves, E. (2019). New WC-Cu composites for the divertor in fusion reactors. Journal of Nuclear Materials,
521,

31-37.

https://doi.org/10.1016/j.jnucmat.2019.04.026

Fathy, A., Wagih, A. and Abu-Oqail, A. (2019). Effect of $\mathrm{ZrO}_{2}$ content on properties of $\mathrm{Cu}-\mathrm{ZrO}_{2}$ nanocomposites synthesized by optimized high energy ball milling. Ceramics International, 45(2:A), 2319-2329. https://doi.org/10.1016/j.ceramint.2018.10.147

Fan, X., Huang, X., Liu, Q., Ding, H. Wang, H. and Hao, C., (2019). The microstructures and properties of in-situ $\mathrm{ZrB}_{2}$ reinforced $\mathrm{Cu}$ matrix composites. Results in Physics, 14(102494), 1-6. https://doi.org/10.1016/j.rinp.2019.102494

Hossein, A., Reza, E. and Baghchesara, M. A. (2014). Investigation of microstructure and mechanical properties of nano $\mathrm{MgO}$ reinforced $\mathrm{Al}$ composites manufactured by stir casting and powder metallurgy methods: A comparative study. Composites Part B: Engineering, 56, 217221.https://doi.org/10.1016/j.compositesb.2013. 08.023

Kargul, M., Borowiecka-Jamrozek, J. and Konieczny, M. (2018). The effect of reinforcement particle size on the properties of $\mathrm{Cu}-\mathrm{Al}_{2} \mathrm{O}_{3}$ composites. IOP Conference Series: Materials Science and Engineering, 461(012035), 1-6. https://doi.org/10.1088/1757899X/461/1/012035

Kumar, M., Gupta, G. K., Modi, O. P., Prasad, B. K., Khare, A. K. and Sharma, M. (2017). Effect of separate and combined milling of $\mathrm{Cu}$ and $\mathrm{TiB}_{2}$ powders on the electrical and mechanical properties of $\mathrm{Cu}-\mathrm{TiB}_{2}$ composites. The Canadian Journal of Metallurgy and Materials Science, 56(1), 58-66. https://doi.org/10.1080/00084433.2016.1247129

Lakshmanan, P., Dharmaselvan, S., Paramasivam, S., Kumar Kirubanandan, L. and Vigneshi R. (2019). Tribological properties of $\mathrm{B}_{4} \mathrm{C}$ nano particulates reinforced copper matrix nanocomposites. Materials Today: Proceedings, 16 , 584-591. https://doi.org/10.1016/j.matpr.2019.05.132

Leich, L., Röttger, A., Kuchenbecker, R. and Theisen, W. (2020). Electro-discharge sintering of nanocrystalline $\mathrm{NdFeB}$ magnets: process parameters, microstructure, and the resulting magnetic properties. Journal of Materials Science: Materials in Electronics, 31, 2043120443. https://doi.org/10.1007/s10854-02004562-6

Li, J., Li, Y., Wang, Z., Bian, H., Hou, Y., Wang, F., Xu, G., Liu, B. and Liu, Y. (2016). Ultrahigh oxidation resistance and high electrical conductivity in copper-silver powder. Scientific 

$\begin{array}{lcc}\text { Reports, } & 6(39650), & 1-10 . \\ \text { https://doi.org/10.1038/srep39650 } & \end{array}$

Li, X., Wang, Y., Yin, C.-R. and Yin, Z. (2020). Copper nanowires in recent electronic applications: progress and perspectives. Journal of Materials Chemistry $\quad C, \quad 8(3), \quad 849-872$. https://doi.org/10.1039/C9TC04744A

Lin, H., Guo, X., Song, K., Feng, J., Li, S. and Zhang, X. (2021). Synergistic strengthening mechanism of copper matrix composite reinforced with nano- $\mathrm{Al}_{2} \mathrm{O}_{3}$ particles and micro-SiC whiskers. Nanotechnology Reviews, 10(1), 62-72. https://doi.org/10.1515/ntrev-2021-0006

Matvienko, O., Daneyko, O., Kovalevskaya, T., Khrustalyov, A., Zhukov, I. and Vorozhtsov, A. (2021). Investigation of stresses induced due to the mismatch of the coefficients of thermal expansion of the matrix and the strengthening particle in aluminum-based composites. Metals, 11(279), 1-20. https://doi.org/10.3390/met11020279

Moustafa, E. B. and Taha, M. A. (2021). Evaluation of the microstructure, thermal and mechanical properties of $\mathrm{Cu} / \mathrm{SiC}$ nanocomposites fabricated by mechanical alloying. International Journal of Minerals, Metallurgy and Materials, 28(3), 475486. https://doi.org/10.1007/s12613-020-2176-z

Ngai, T. L., Zheng, W. and Li, Y. (2013). Effect of sintering temperature on the preparation of $\mathrm{Cu}-$ $\mathrm{Ti}_{3} \mathrm{SiC}_{2}$ metal matrix composite. Progress in Natural Science: Materials International, 23(1), 70-76.

https://doi.org/10.1016/j.pnsc.2013.01.011

Oghbaei, M. and Mirzaee, O. (2010). Microwave versus conventional sintering: A review of fundamentals, advantages and applications. Journal of Alloys and Compounds, 494, 175-189. https://doi.org/10.1016/j.jallcom.2010.01.068

Panda, S., Dash, K. and Ray, B. C. (2014). Processing and properties of $\mathrm{Cu}$ based micro- and nanocomposites. Bulletin of Materials Science, 37(2), 227-238. https://doi.org/10.1007/s12034-0140643-8

Pellizzari, M. and Cipolloni, G. (2020). Spark plasma sintering of copper matrix composites reinforced with $\mathrm{TiB}_{2}$ particles. Materials. 13(2602), 1-14. https://doi.org/10.3390/ma13112602

Raab, S. J., Guschlbauer, R., Lodes, M. A. and Körner, C. (2016). Thermal and electrical conductivity of 99.9\% pure copper processed via selective electron beam melting. Advanced Engineering Materials, 18(9), 1661-1666. https://doi.org/10.1002/adem.201600078
Raj, S. S., Elavarasan, E., Arundeva, S., Devaraj, S., Gokulraj, E. and Govindharasu. C. (2018). Tribological test on copper based hybrid composite material, International Journal of Engineering Research \& Technology (IJERT) ICITMSEE, 6(10), 1-4.

Ren, J., Liang, S., Jiang, Y. and Du, X. (2019). Research on the microstructure and properties of in situ $\left(\mathrm{TiB}_{2}-\mathrm{TiB}\right) / \mathrm{Cu}$ composites. Acta Metallurgica Sinica, 55(1), 126-132. https://doi.org/10.11900/0412.1961.2017.00532

Saheb, N. (2013). Spark plasma and microwave sintering of Al6061 and Al2124 alloys. International Journal of Minerals, Metallurgy and Materials, 20(2), 152-159. https://doi.org/10.1007/s12613-013-0707-6

Sathish, T., Chandramohan, D., Vijayan, V. and Sebastian, P. J. (2019). Investigation on microstructural and mechanical properties of $\mathrm{Cu}$ reinforced with $\mathrm{SiC}$ composites prepared by microwave sintering process. Journal of New Materials for Electrochemical Systems, 22, 5-9. https://doi.org/10.14447/jnmes.v22i1.a02

Satishkumar, P., Mahesh, G., Meenakshi, R. and Vijayan, S. N. (2021). Tribological characteristics of powder metallurgy processed $\mathrm{Cu}-\mathrm{WC} / \mathrm{SiC}$ metal matrix composites. Materials Today: Proceedings, 37, 459-465. https://doi.org/10.1016/j.matpr.2020.05.449

Schipper, B. W. Lin, H. -Ch. Meloni, M. A. Wansleeben, K. Heijungs, R. and Van der Voet, E. (2018). Estimating global copper demand until 2100 with regression and stock dynamics. Resources, Conservation and Recycling, 132, 2836.https://doi.org/10.1016/j.resconrec.2018.01.0 04

Shaik, M. A. and Golla, B. R. (2020). Two body abrasion wear behaviour of $\mathrm{Cu}-\mathrm{ZrB}_{2}$ composites against $\mathrm{SiC}$ emery paper. Wear, 450451(203260), 1-14. https://doi.org/10.1016/j.wear.2020.203260

Singh, M. K., Gautam, R. K. and Ji, G. (2019). Mechanical properties and corrosion behavior of copper based hybrid composites synthesized by stir casting. Results in Physics, 13(102319), 1-11. https://doi.org/10.1016/j.rinp.2019.102319

Solodkyi, I., Bezdorozhev, O. and Loboda, P. (2020). High electrical conductive copper matrix composites reinforced with $\mathrm{LaB}_{6}-\mathrm{TiB}_{2}$ eutectic particles. Vacuum, 177(109407), 1-4. https://doi.org/10.1016/j.vacuum.2020.109407

Somani, N., Sharma, N., Sharma, A., Gautam, Y. K., Khatri, P. and Solomon, J. A. A. (2018). Fabrication of $\mathrm{Cu}-\mathrm{SiC}$ composites using powder metallurgy technique. Materials Today: 
Proceedings, 5(14:2), 28136-28141. https://doi.org/10.1016/j.matpr.2018.10.055

Sridhar, M. M. J., Ravichandran, M. and Meignanamoorthy, M. (2020). Influence of different reinforcements on properties of copper matrix composites: A review. AIP Conference Proceedings, 2283(020129), 1-10. https://doi.org/10.1063/5.0029257

Strojny-Nędza, A., Pietrzak, K., Gładki, A., Nosewicz, S., Jarząbek, D. M. and Chmielewski, M. (2018). The effect of ceramic type reinforcement on structure and properties of $\mathrm{Cu}-\mathrm{Al}_{2} \mathrm{O}_{3}$ composites. Bulletin of the Polish Academy of Sciences. Technical Sciences, 66(4), 553-560. https://doi.org/10.24425/124271

Suárez, M., Fernández, A., Menéndez, J. L., Torrecillas, R., Kessel, H. U., Hennicke, J., Kirchner, R. and Kessel, T. (2013). Challenges and opportunities for spark plasma sintering: a key technology for a new generation of materials. B. Ertug (Ed.), Sintering Applications (pp 319-342). London: IntechOpen. http://dx.doi.org/10.5772/53706

Taha, M. A. and Zawrah, M. F. (2017). Effect of nano $\mathrm{ZrO}_{2}$ on strengthening and electrical properties of $\mathrm{Cu}$-matrix nanocomposites prepared by mechanical alloying. Ceramics International, 43(15), 12698-12704. https://doi.org/10.1016/j.ceramint.2017.06.153
Tejado, E., Müller, A. V., You, J.-H. and Pastor, J. Y. (2018). The thermo-mechanical behaviour of W$\mathrm{Cu}$ metal matrix composites for fusion heat sink applications: The influence of the $\mathrm{Cu}$ content. Journal of Nuclear Materials, 498, 468-475. https://doi.org/10.1016/j.jnucmat.2017.08.020

Wang, C., Min, G. and and Kang, S. (2011). Thermal conducting property of SiCp-reinforced copper matrix composites by hot pressing. Journal of Composite Materials. 45(18), 1849-1852. https://doi.org/10.1177/0021998310387685

White, G. K. and Tainsh, R. J. (1960). Lorenz number for high-purity copper. Physical Review Journals Archive, 119(6), 1869-1871. https://doi.org/10.1103/PhysRev.119.1869

Ye, X. -P., Li, Y. -L., Weng, J. -D., Cai, L. -C. and Liu, C. -L. (2018). Research status on strengthening mechanism of particle-reinforced metal matrix composites. Journal of Materials Engineering, 46(12), 28-37. https://doi.org/10.11868/j.issn.10014381.2016 .001214

Yin, J., Zhou, P., Liang, H., Yao, D., Xia, Y., Zuo, K. and Zeng, Y. (2020). Microstructure and mechanical properties of $\mathrm{Cu}$ matrix composites reinforced by $\mathrm{TiB}_{2} / \mathrm{TiN}$ ceramic reinforcements. Acta Metallurgica Sinica (English Letters), 33, 1609-1617. https://doi.org/10.1007/s40195-02001100-5 